\title{
On the Distribution of an Endemic Geometrid Moth, Xanthorhoe inconsiderata (Staudinger, 1892) (Lepidoptera)
}

\author{
Erdem SEVEN ${ }^{1}$
}

ABSTRACT: In this study, distributional and ecological information about an endemic geometrid moth Xanthorhoe inconsiderata (Staudinger, 1892), which is distributed only in Turkey, is presented. It is reported as new for the Lepidoptera fauna of Siirt Province from southeastern Turkey. The genitalia pictures of male and female of the species are submitted for the first time.

Keywords: Lepidoptera, Geometridae, Xanthorhoe inconsiderata, Turkey

\section{Xanthorhoe inconsiderata (Staudinger, 1892), Endemik Bir Geometrid Güvenin Yayılışı Üzerine (Lepidoptera)}

ÖZET: Bu çalışmada, sadece Türkiye'de dağılış gösteren, endemik bir geometrid güvenin Xanthorhoe inconsiderata (Staudinger, 1892), yayılışı ve ekolojisi hakkında bilgi verilmiştir. Bu tür, Türkiye’nin Güneydoğusundaki Siirt ilinin Lepidoptera faunasında yeni tespit edilmiştir. Türün erkek ve dişi genital resimleri ilk kez sunulmaktadır.

Anahtar Kelimeler: Lepidoptera, Geometridae, Xanthorhoe inconsiderata, Türkiye

Department of Gatronomy and Culinary Arts, School of Tourism and Hotel Management, Batman University, Batman, Turkey, e-mail: erdem_seven@hotmail.com 


\section{INTRODUCTION}

In the family Geometridae, the valid genus name Xanthorhoe was advised by Hübner in 1825 . This genus is distributed worldwide with 228 species (Scoble, 1999), 62 species are described from the Palaearctic region and 20 of them occurring in Europe (Hausmann and Viidalepp, 2012). And 11 species are hitherto known from Turkey: Xanthorhoe biriviata (Borkhausen, 1794), $X$. decoloraria (Esper, [1806]), X. designata (Hufnagel, 1767), X. ferrugata (Clerck, 1759), X. fluctuata (Linnaeus, 1758), $X$. inconsiderata (Staudinger, 1892), X. montanata ([Denis \& Schiffermüller], 1775), X. oxybiata (Millière, 1872), X. rectifasciaria (Lederer, 1853), X. spadicearia ([Denis \& Schiffermüller], 1775) and X. quadrifasciata (Linnaeus, 1761) (Koçak and Kemal, 2009; Koçak, 2014). Recent current studies on Geometridae species for Siirt Province belong to Kemal and Seven, (2013) and Seven, (2014). Even though numbers of the species are not too many, external morphological characters are not sufficient for exact diagnosis in this group.

In this study, pictures of adults and genitalia of Xanthorhoe inconsiderata (Staudinger, 1892), which is endemic and known only from Turkey, are presented. Furthermore, data on new locality and phenology of the species are given.

\section{MATERIALS AND METHODS}

The study materials were collected in 2013 from Bacavan Mountain, Şirvan district, Siirt Province, South-eastern of Turkey within the framework of the doctoral programme. But it could not be accurately diagnosed during the thesis (Seven, 2014). After further investigation, it was understood that only data for the species was given by Staudinger in 1892 for description of the species (without figures). And Hausmann (2011) has given short textual information about genitalia of $X$. inconsiderata when describing and comparing with sibling species $X$. pederi Hausmann \& Friedrich, 2011, which was collected from Cyprus. However, could not be found its genitalia figures in any source. Therefore, the species is compared with in the Munich Museum (Zoologische Staatssammlung Muenchen) to identify them at the species level. The processed materials are deposited in the laboratory of Batman University, Faculty of Arts and Sciences, Department of Biology.

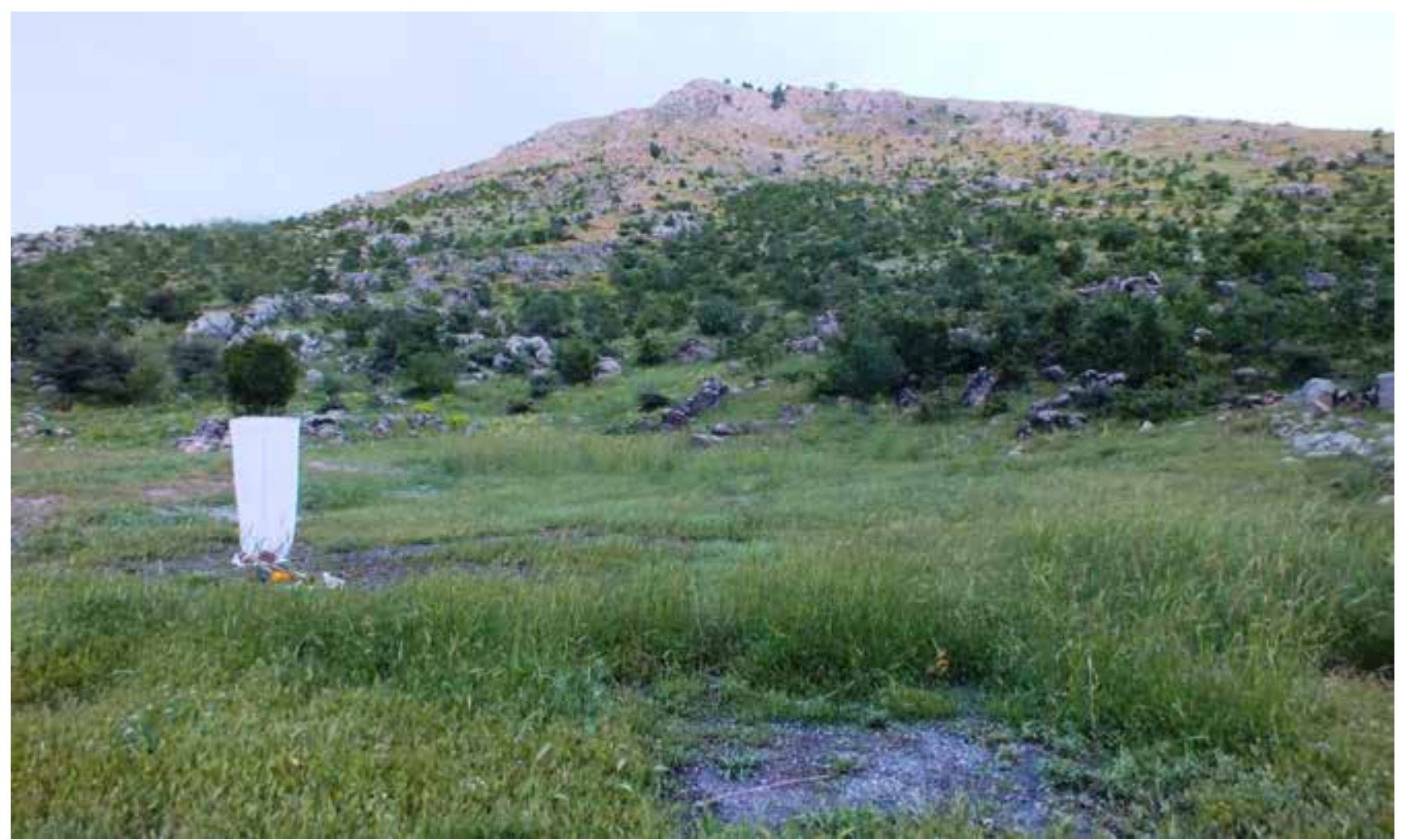

Figure 1. Habitat of $X$. inconsiderata (Staudinger, 1892): Turkey, Siirt Province, Sirvan district, Bacavan Mountain, 1500 m, 29.5 .2013$. (photo E. Seven) 


\section{RESULTS AND DISCUSSION}

In this research, the author has presented information about endemic $X$. inconsiderata moth, which is known only in Turkey from a small area. The specimens fly 1500-1600 m above sea-level in October at night. Bacavan Mountain, where is the habitat of the specimens, is containing rocky areas and including intensely Crataegus and Quercus species with Juniperus and Paliurus plants (Figure 1). In addition, the area contains various herbaceous plant species in the family Asteraceae, Poaceae, Brassicaceae and Rubiaceae. Larva is unknown but in current study it is estimated that feed on herbaceous plants in the family Brassicaceae or Rubiaceae such as other Xanthorhae species (Hausmann and Viidalepp, 2012) distributed in Europe.

Examined materials: $1 \sigma^{*} 19$ Turkey, Siirt prov., Şirvan, Bacavan Mountain, 1560 m,
12.10.2013 (Genital slides no: Gp285 9, Gp2920') (Figure 2. a-d). 1

Diagnosis: Male antennae bipectinate, female antennae filiform. Medial area of forewing contrasted against ground colour, darker. Discal spot sharp and black. Postmedial fascia narrow, covered with greyish scales. Terminal region of forewing completely dark, wavy line remarkable at the whole length.

Hindwing with basis and terminal region darker, postmedial fascia in some degree straight. Male genitalia: Costa of valva at tip stouter.

Ventral part of pronged costal tip connected to centre of valvula. Female genitalia: Ductus bursae straight, sclerotised. Corpus bursae globular, signum in posterior position, strongly improved as a large semicircular darn of little spines.
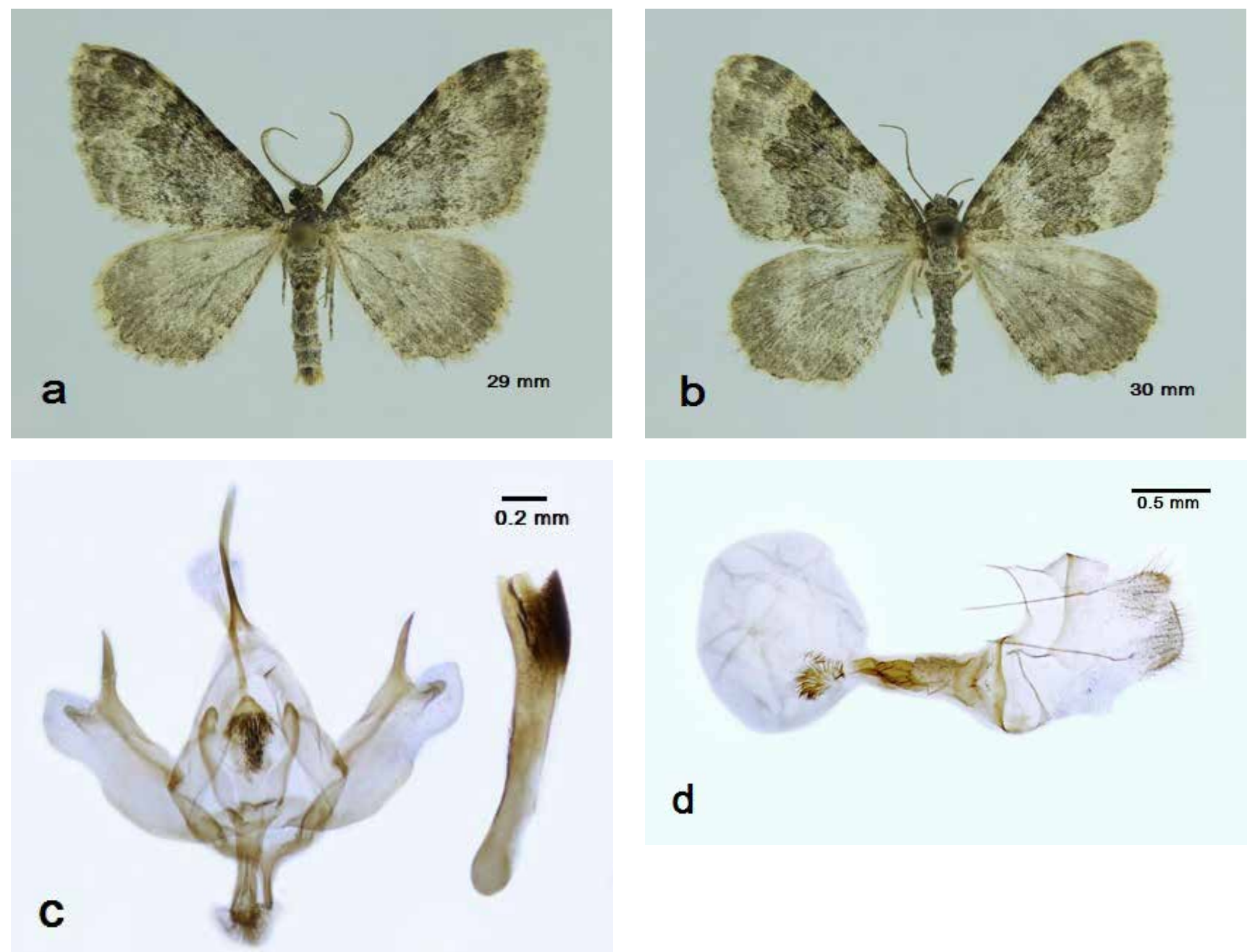

Figure 2. a-b. The adult and c-d. genitalia pictures of male and female of X. inconsiderata (Staudinger, 1892). (photos E. Seven) 
In the original description, $X$. inconsiderata (Staudinger, 1892) was introduced based on two male specimens from Amasya Province.

Later, this species was recorded by Wherli (1934) from Kahramanmaraş Province (samples in Munich Museum). In this study, it is presented from Siirt Province, where is new locality. Specimens in this study are stored in a local collection in Turkey, while other samples are in the foreign museums. In addition,

\section{REFERENCES}

Hausmann A, 2011. An integrative taxonomic approach to resolving some difficult questions in the Larentiinae of the Mediterranean region (Lepidoptera, Geometridae). - Mitt. Münchn. Ent. Ges. 101: 73-97.

Hausmann A, Viidalepp J, 2012. The Geometrid Moths of Europe. 3. volume, Apollo Books, Stenstrup.

Kemal M, Seven E, 2013. Studies on the fauna and ecology of the Geometridae (Lepidoptera) in Şirvan district (Siirt Province, SE Turkey) . Cent. ent. Stud., Priamus (Suppl.) 29: vi+1-41.

Koçak AÖ, Kemal M, 2009. Revised Checklist of the Lepidoptera of Turkey. Centre entomological studies, Priamus supplement $17,1-253$.

Koçak A, 2014. List of the 23773 Pterygot species in Turkey based upon the info-system of the Cesa. Priamus (Supplement) 32, $1-876$. genitalia pictures of male and female of the species are submitted for the first time.

\section{ACKNOWLEDGEMENTS}

The author is grateful to Dr. Axel Hausmann (Munich, Germany) and Dr. Ahmet Ö. Koçak, Dr. Muhabbet Kemal Koçak (Van, Turkey) for their help in determining of the species and valuable advice.

Scoble MJ, 1999. Geometrid moths of the world: a catalogue (Lepidoptera, Geometridae). Vols. 1, 2. Apollo Books, Stenstrup, pp. 1-116.

Seven E, 2014. Eco-faunistic studies on the Macroheterocera species in Şirvan district of Siirt (Lepidoptera). Ph.D. Thesis. Yuzuncu Y1l University, Van, Turkey, [unpublished] (in Turkish). xvii +427 .

Staudinger O, 1892. Neue Arten und Varietäten von Lepidopteren des paläarktischen Geometriden. Deutsche Entomologische Zeitschrift, Iris 5 (1): 141-260.

Wehrli E, 1934. Lepidopterenfauna von Marasch in Türkisch Nordsyrien (Fortsetzung) - Die Geometriden der Ausbeute. Mitteilungen der Münchner Entomologischen Gesellschaft 024: $25-55$. 